\title{
National Leader, International Actor
}

\author{
I have a picture of Mussolini in a scene in which I am directing him how \\ to act. \\ GEORGE FITZMAURICE, DIRECTOR OF THE ETERNAL CITY, $1924^{1}$
}

Italy's pet fire eater is the star of the newsreel sections.

PICTURE-PLAY MAGAZINE, $1924^{2}$

The literature on Mussolini's relationship to motion pictures within the Italian context has been extremely rich, particularly since the late 1970s. It has generally focused on the extent to which the Fascist government, through various ministers, programs, and talented individuals, sought to exercise an effective control over film production, distribution, and exhibition. The creation of the newsreel agency Istituto LUCE (L'Unione per la Cinematografia Educativa) in 1924, the sponsor of the Venice Film Festival in 1931, the creation of the ENIC (Ente Nazionale dell'Industria Cinematografica [General Directorate of Cinematography]) in 1935, and the building of Cinecittà Studios in 1937 are just some of the milestones of the regime's efforts to control most aspects of Italian film culture. ${ }^{3}$ A growing literature has focused on the ways in which Mussolini's actions and images came to dominate several aspects of this culture-from newsreels to film stardom. ${ }^{4}$ Finally, more recent scholarly attention has been given to the cult of Mussolini within Italian film culture and in other forms of mass communications. ${ }^{5}$

The Fascist government, however, could only indirectly control Mussolini's screen presence and circulation in the United States, in terms of both Italian and American productions. The regime had to enter into partnerships with Hollywood studios, newsreel companies, and distribution firms; to negotiate directly with the MPPDA to ensure what it deemed a fair national representation; and sometimes to establish agreements with private distributors and individual theaters (which often ended in disappointment). What kind of stories about itself could the regime sell to Americans? The conventional distinction between Fascism as movement and as regime, articulated by Renzo De Felice in his monumental biography of the Duce and his study of Fascism's institutionalization, does not apply to its American representation. ${ }^{6}$ Fascism as either a violent movement, a complex historical 
phenomenon, or an autocratic ideology was not commercially viable in democratic America. Instead, Fascism could be sold as a triumphant administrative solution to the challenges that every government faces. Yet even a well-organized regime could not easily be translated into a popular narrative: a national arrangement centered on a single public personality, bigger than any movement or regime, was preferable. This possibility rested on a caveat that concerned Mussolini's American middlemen. Casting the Duce as the Fascist regime's celebrity-performer meant inserting him in fictional or nonfictional narratives that were familiar to the American public but that were not of his own making or under his control. ${ }^{7}$ Early fictional productions from Italy, especially when set in Roman times and thus aligned with the regime's celebration of Rome's political history, were no longer appealing to American audiences. The case of Messalina (1924), a passé historical epic by Enrico Guazzoni, who ten years earlier had directed Quo Vadis? (1913), is symptomatic. American trade papers maintained that costly Italian historical productions relied on financial backing from Mussolini's regime and served his interests. ${ }^{8}$ The film struggled to find distributors who did not prefer the superior production values of Fox's colossal Dante's Inferno (1924). ${ }^{9}$

The distinction between productions from Italy and from the United States is a productive one, but it is also complicated by the fact that several key American productions were shot in Italy and as such were not divorced from the regime's tentative reach. The case of The Eternal City (1924), a modern political melodrama produced by a Hollywood studio and filmed in Rome, is extremely illuminating of the kind of intense negotiations that Hollywood and the regime's middlemen engaged in not long after the March on Rome.

\section{THE ETERNAL CITY}

As we have all come to realize, even the most important of "international relations" have to be carried on by individuals.

WILL H. HAYS, $1955^{10}$

With the possible exception of a few brief newsreel sequences, the first opportunity for Mussolini to be screened across America was through the Goldwyn production The Eternal City. Besides granting cinematic visibility to a dictator that some in the press had been raving about for almost two years, the film is important for two other reasons. On a production level, it identifies the various institutional and commercial parties interested in the propagation of Fascism and its leader in America. On the level of reception, it shows what Mussolini and his American representatives came to learn about political propaganda.

Directed by George Fitzmaurice and written by his wife, Ouida Bergère, The Eternal City was filmed in Rome in the summer of 1923 just a few months after the March on Rome. ${ }^{11}$ Italy was not an uncommon destination for several 


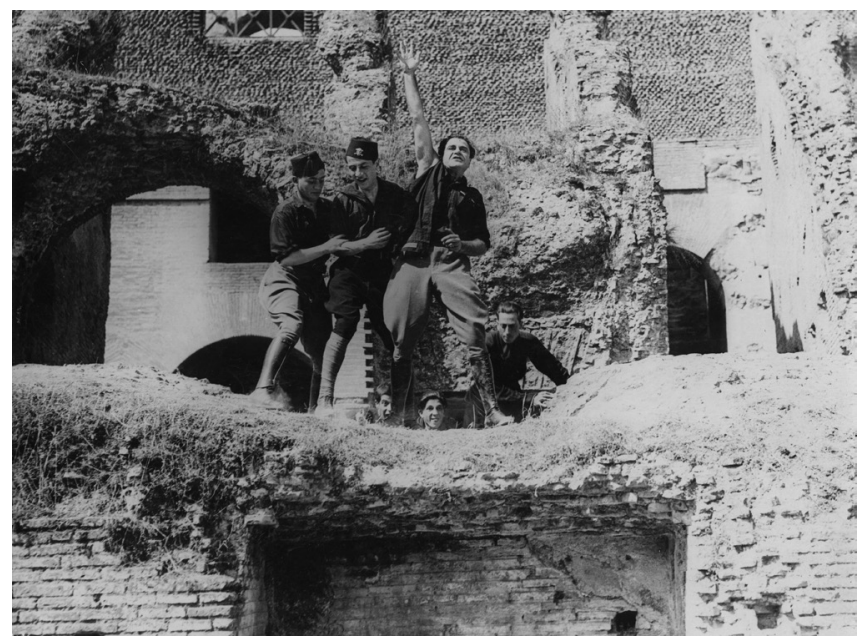

FIGURE 36. Fascist leader David Rossi (Bert Lytell) rallying his supporters inside the Coliseum, before clashes with Socialist adversaries in The Eternal City (1924). Courtesy of Museum of Modern Art Film Stills Archive.

Hollywood companies at the time. Fitzmaurice, who would direct The Son of the Sheik in 1926, had already filmed The Man from Home (Famous Players-Lasky, May 1922) in Sorrento. ${ }^{12}$ According to Goldwyn's biographer A. Scott Berg, it was Fitzmaurice who had "recommended a play Paramount had filmed in 1915, Sir Hall Caine's 'The Eternal City" ' and it was Ouida Bergère who had "suggested updating this love story, set against post-Risorgimento Rome, to Mussolini's Italy." ${ }^{13}$ At the turn of the century, the British writer Hall Caine (1853-1931) was extraordinarily popular. He had originally conceived The Eternal City as a play but published it as a novel in 1901. It became his most successful work. It would be translated into thirteen languages and sold more than a million copies in English alone. The stage version was also a success in both the United Kingdom and the United States. ${ }^{14}$

The story is a political romance in which the hero, David Rossi (Bert Lytell), is accused of plotting to murder the Italian king. The screen adaptation changed the story's political color from a celebration of socialist heroism to one of Fascist victory. In this updated film version, the hero is now Mussolini's right-hand man, whose beloved Donna Roma (Barbara La Marr) first appears to be on the wrong political side due to her close rapport with a Communist villain, Baron Bonelli (Lionel Barrymore), before she reveals her loyalty to her man. After scenes of mass gatherings of Fascist sympathizers at the Coliseum and clashes with the Communist rivals, the film climaxes in an actual view of a victorious Mussolini on the balcony of the royal palace, beside the Italian king, and David and Donna's romantic reunion (figures 36 and 37 ). 


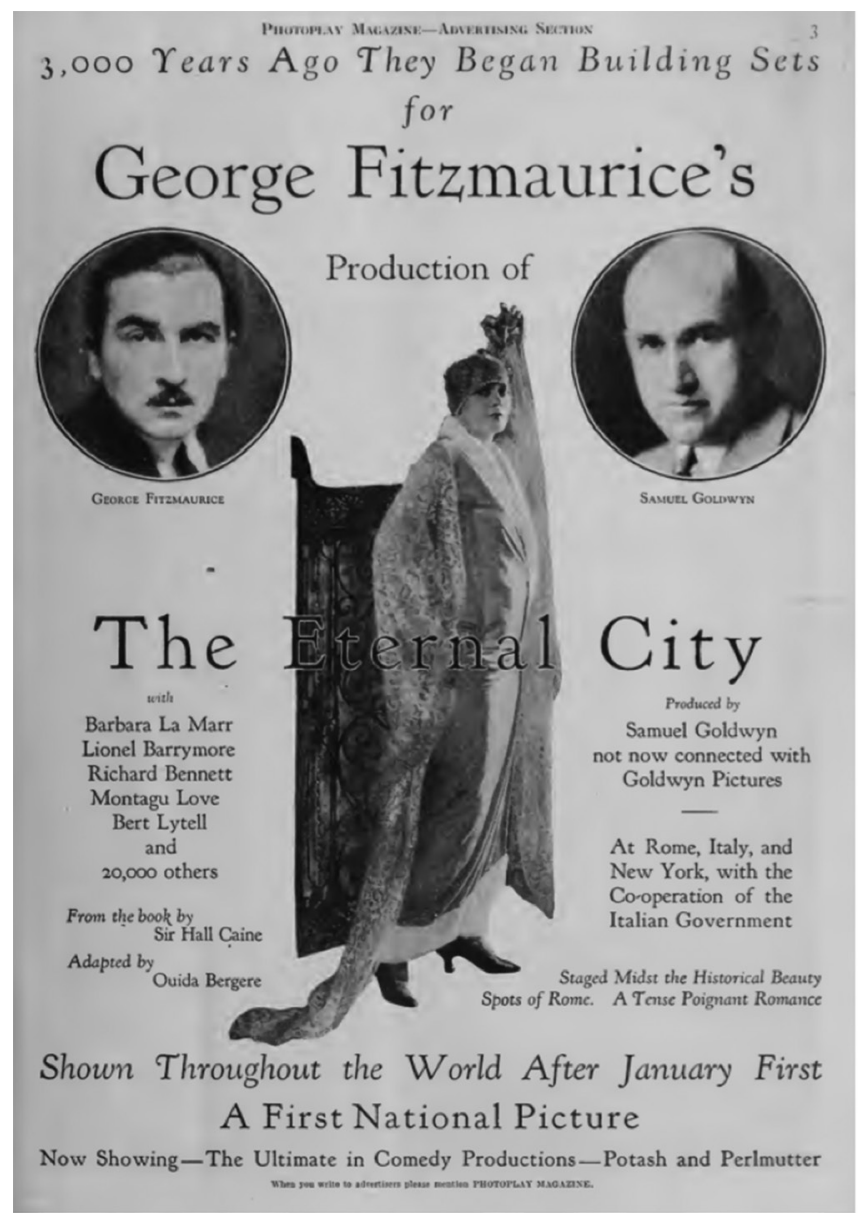

FIGURE 37. The Eternal City (1924), full-page advertisement, Photoplay, January 1924, 3.

The extent to which the Fascists contributed financially and logistically to the filming of The Eternal City has long remained unclear. Berg suggests that "when the Fascists caught wind of the film and demanded its confiscation, Fitzmaurice and his crew quickly left the country," and the cinematographer "smuggled the negative safely out of Italy." ${ }^{15}$ The archival evidence tells a slightly different story. The embassy's press clipping service and the correspondence of the Italian ambassador Gelasio Caetani with several individuals, from Fitzmaurice and MPPDA head Will H. Hays to various Italian ministers and even Mussolini himself, shed light on the circumstances of the film's production, final version, and commercial distribution. They also reveal how American producers and Italian authorities sought to work together to promote the film. 
This is not a story of a well-planned and direct public relations campaign in favor of Mussolini but of a series of collaborative attempts between Hollywood filmmakers and Italian authorities to enable the production and distribution of a supportive and profitable film. The Eternal City also constituted a learning curve for the Italian officials involved: while they quickly regarded it as a unique opportunity for effective propaganda, they were initially unaware of the commercial imperatives of American film culture. The archival record does not include documents that reveal who approached whom, but they suggest that upon Goldwyn's request, Hays first contacted Ambassador Caetani to assess whether the Italian government was in favor of the production and was willing to support it.

Caetani's initial support of the film was likely due to the Fascist regime's new directive about the importance of motion pictures for political communication. That directive had come down as a ministerial circular (no. 16) from Mussolini himself in his role as minister of foreign affairs and was widely distributed on March 1, 1923. Devoted to propaganda abroad, the Duce's directive centered on the cinematic medium. For Mussolini, films were to illustrate "in an attracting and interesting way the wealth and power of our industries, the unmatched natural and artistic beauty of Italy [...] while always culminating with glorifying visions of our army and military forces." The circular informed all interested parties-mostly diplomats, ambassadors, and consuls - that Mussolini had created a commission of experts who were to curate the publication of literary works that would faithfully reproduce in words what films showed on screen. ${ }^{16}$ Considering how carefully Caetani would always approach the issue of Fascist propaganda in America, being aware of the obvious risks of meddling with American politics, the opportunity to support an American production by established Hollywood filmmakers that featured the Duce must have seemed more than intriguing.

Before Mussolini's circular reached his desk, Caetani had already understood the importance of motion pictures for broadcasting a positive image of Italy in America. Earlier that year, he had contacted the MPPDA about past and recent anti-Italian productions. On January 26, 1923, the vice president and secretary of the MPPDA, Courtland Smith, reassured Caetani that "Mr. Hays again desires to assure you that it is our most sacred duty and greatest pleasure to assist in developing international good will and friendly relations with each country, and that our members would not do consciously that which in a broad sense would give offense to any nation." ${ }^{17}$ Caetani immediately copied the letter and conveyed its content to both Mussolini and to the head of the League for the Protection of National Interest, Oscar Sinigaglia. The ambassador added that he had notified the consular offices to collect and submit to him information about anti-Italian productions in order to pressure the MPPDA to secure appropriate measures according to its own promises. ${ }^{18}$ Yet, this rather defensive approach soon gave way to a more assertive one.

One day in April 1923 Caetani phoned Hays, asking for a meeting. He knew that the first American fiction film about Fascism could be, as he wrote to a high Fascist 
official, "most important for our American propaganda."19 But he needed assurances that the production and the final result would turn out to be in accordance with what he considered the story and essence of Fascism. ${ }^{20}$ Hays scheduled the meeting for May 4 and informed Caetani that Sam Goldwyn and George Fitzmaurice, The Eternal City's producer and director, would also be present. ${ }^{21}$ Further, Hays confirmed to the Italian ambassador the MPPDA's policy regarding representations of foreign nations that in terms of diplomatic strategy aligned with the U.S. State Department.

As [Undersecretary of State William] Phillips explained to you $[, \ldots$. . ] it is the earnest purpose of the producer and the Association that the production may square exactly with all of the proprieties and that the picture may be a definite contribution to the progress of international amity. ${ }^{22}$

The meeting took place and apparently went well. Still, as Mussolini's key representative in America, Caetani wanted written assurance about the film's treatment of Fascism. In a letter to Hays, he used the MPPDA chief's own words: "I shall highly appreciate if, as you suggested, this production will give a correct picture of my country and will be a definite contribution to the progress of international amity." Only upon receipt of such written confirmation could Caetani offer all possible help in the form of "letters recommending to the authorities in Italy that all possible facilities be given." ${ }^{23}$ To reassure the ambassador, Hays sent him letters that the MPPDA chief had received from Sam Goldwyn, whose prose was so formal that it was likely written with the explicit goal of sounding like "a very definite commitment," as Hays later described them to Caetani. ${ }^{24}$ The ambassador found these exchanges "quite definite and satisfactory." ${ }^{25} \mathrm{He}$ was further reassured following meetings with the director, Fitzmaurice, and his wife, Ouida Bergère, who was working on adapting Caine's novel to the Fascist context.

Through these exchanges, the practice of a Fascist official mediating between Hollywood and the Italian government started to take hold. In his letter to Hays, Caetani suggested that it was Mrs. Fitzmaurice who had come up with the idea of securing a trusted representative of the ambassador (and the Fascist government) assist them in Rome and correct any historical inaccuracies to avoid subsequent embarrassment. In a June cable to Mussolini, however, Caetani claimed that he was the one who had the idea of inserting a trusted representative to assist, advise, and report about the filming in Rome. That person turned out to be none other than Countess Irene di Robilant, IAS's factotum secretary and Caetani's close collaborator on this and other propaganda initiatives. Both the studio and Hays himself were enthusiastic about her presence, whose power in Italian government circles and knowledge of American and Italian cultures would well serve all the parties involved.

On June 8 Caetani informed Mussolini about The Eternal City's production, mentioning Hays as "the chief of American cinematography," and describing the film as a grandiose $\$ 600,000$ production destined to circulate widely throughout 
the United States. ${ }^{26}$ Caetani told the Duce that he "immediately saw the importance of such an instrument of propaganda." Still, in order to avoid any misunderstanding about "the nature and the spirit of the fascist movement," he informed the Duce that he had managed to secure the presence of di Robilant, whom he described as "secretary and soul of the Italy American Society," to serve as chief location adviser in Italy. He also reassured him that the producers had made every effort to change the plot, avoid mistakes, and return "a correct vision of fascism from its latent state during the early days of the war to the triumph of the March on Rome." Caetani concluded his communication to Mussolini by mentioning that if screened in America's "twenty-five thousand movie theaters," the history of Fascism was bound to be watched by millions of people. ${ }^{27}$ Meanwhile the ambassador had already requested assistance from several key figures in politics, film, and journalism who would support the shooting in terms of logistics (i.e., permits) and publicity.

Instead of overseeing the production from the Italian embassy in Washington, Caetani eventually took matters into his own hands and spent part of that summer in Rome. His goal was to assist his intermediaries, particularly di Robilant, not just with logistics, particularly for the large scenes featuring army and cavalry soldiers, but also and more significantly in securing the film's ideological integrity and controlling the publicity narrative. ${ }^{28}$ Caetani wanted to have his name associated with a production that stressed the political novelty of the regime. On July 25, 1923, Il Giornale d'Italia described a production supervised by the "tireless Prince Caetani," that promised to offer "a clear and synthetic view of the fascist movement, in its ethical essence and in its patriotic and political goals." The promotional article highlighted the same figures that the ambassador had used in his communication with Mussolini: millions of spectators attending the country's "twenty-five thousand movie theaters" were bound to enjoy this most "efficacious propaganda of Italianness." 29

Filming did not go smoothly. In mid-July the Italian chief of police, Emilio De Bono, informed Caetani that he was concerned about scenes showing wretched returning soldiers, widespread poverty, and communists spitting on the Italian flag..$^{\circ}$ Caetani must have shared his own concern with the filmmakers. In late July, Fitzmaurice reassured him by offering him the chance to "view the picture in New York upon its completion." The director also granted the ambassador the opportunity of correcting any error "to insure that our picture will be a true representation of your great movement." ${ }^{31}$ The publicity machine was already active in America too, but here it was out of Caetani's direct control.

On August 28, 1923, a long article appeared in the White Plains Reporter; it included an interview with Fitzmaurice about filming The Eternal City in Fascist Italy. Variously edited, sections of the interview eventually made their way into the trade press. The director certainly said a few of the right things, including the fact that the filmmakers "received a great deal of help from the Government and were permitted to go everywhere." In a few instances, however, Fitzmaurice's answers 
were problematic, particularly when he revealed that Fascism had many detractors in Italy. "When we reached Rome," he noted, "some of the people were glad that we were to make a Fascist production, while others were opposed to the idea." Further, Caetani feared that the director's public insistence that the film did not constitute "good propaganda" was going to exert the opposite effect and hurt the film's commercial potential. His more disturbing statements pertained to Mussolini's participation. "I even photographed Mussolini in the picture," he boasted, "and in a sort of prologue, which we call a trailer, I have a picture of Mussolini in a scene in which I am directing him how to act." ${ }_{32}$ In effect, Fitzmaurice's statement reduced Mussolini to an actor working for a Hollywood director, a mere performer in a story that the Italian leader had not supervised and over which he exercised only indirect influence through his subordinates. This statement ran against all the publicity narratives that had made the Duce the cognizant and in-charge protagonist of a historical event.

In addition, The Eternal City itself did not match the Fascist officials' expectations. Caetani returned to Washington in late September and, upon Goldwyn's invitation, watched the film in New York on November $15 .{ }^{33}$ Di Robilant had seen it a week before and had shared her disappointment with the ambassador. While she did not find much objectionable about the production-except for an intertitle that read "in a country famous for its vagabonds" - she nonetheless found it overall "dull." In her view "the whole [Fascist] movement appears entirely to have been censored as a strike-breaking organization." She added:

Nothing of the history of spirituality of the movement itself appears, and this is all the more astonishing, when we remember how hard we all worked, exactly on that part. I have written pages and pages of history, we arranged for patriotic visions, and some of that material was actually photographed. For commercial reasons it has not been included in the picture. ${ }^{34}$

Her final impression was that The Eternal City "would not even be a financial success. There is no thrill, and the story is not exciting. The end falls entirely flat." Disappointed, she feared that upon seeing the film, Fascist officials would criticize her and the ambassador. She had expected much more "after having disturbed the Duce, the Army, the Police." ${ }^{35}$

Di Robilant's impression influenced Caetani's. After watching the film, he did not hesitate to convey his disappointment to Goldwyn. Caetani had many reservations about missing or incomplete intertitles that he felt were needed to explain the historical context. He also did not appreciate the scarcity of iconic images, whether related to World War I or "the fascists saluting with extended arms during the march on Rome." Revealing an unexpected understanding of film editing, he told di Robilant about his advice to Fitzmaurice that the Duce's "pictures would not be inserted in the play, but would either precede or follow the film." ${ }^{36}$ Eloquently emphasizing the political stakes, Caetani declared that he could not agree that 
Mussolini should appear as "one of the actors of the Goldwyn Company." ${ }^{37}$ This was also sensitive promotional issue that affected the Duce's standing in relationship to the film's narrative. Mussolini was the demiurge of the Fascist movement, after all, and his relevance could not be portrayed as secondary. The Duce was certainly an actor and a performer-as the anti-Fascist literature recognized early on and would continue to do for years-but in his own show, not someone's else's.

Caetani had ideas. "The picture of Mussolini at his desk," he wrote to di Robilant, "should be placed immediately after that of the King standing at the balcony. It could be preceded by a caption saying: 'This is Mussolini the man who organized the whole Fascisti movement and is now head of the Government." "38 The surviving copy of the film features the image of the Duce at his desk following that of the king, but not the suggested additional intertitle. ${ }^{39}$ Secondly, to address the problem of "authorship," Caetani and the studio agreed to insert a statement from Mussolini that would have framed the entire film as overseen and approved by the Duce. The Eternal City premiered on January $20,1924,{ }^{40}$ but four days later the ambassador was still working on tweaking the film's intertitles. On January 24, he informed Fitzmaurice that Mussolini had completed the "message to be used in connection with the exhibition" of the film. It read:

Italy, by means of her gallant and strenuous fascisti youth has established order throughout towns and country; by a noble will effort she has gained civic peace which allows her to work and progress.

Fascismo, in the history of Modern Europe, will remain an unparalleled example of moral energy and of spontaneous self-sacrifice devoted to the cause of civilization which is essentially the cause of order, of work and of national and social discipline. [Signed] Mussolini ${ }^{41}$

By then, the film had been distributed by First National and had premiered at the Strand Theater in New York City. It was an impressive production, with the theater's symphony orchestra playing Pietro Mascagni's popular Cavalleria rusticana. Naturally, Caetani was unnerved, fearing that a propaganda film qua propaganda would not work. He asked the consul general of Italy, Temistocle Filippo Bernardi, to have someone whom he trusted visit movie theaters where the film was being shown and report back to him. ${ }^{42}$ He wanted to know whether the film's nonpolitical advertisements were having any impact on the film's reception in New York City. In early February, the consul communicated to the ambassador that The Eternal City was having some success with audiences, particularly when Mussolini and Fascist actions were on the screen. He also noted that early scenes featuring beggars and a robber would not help Italy's reputation. His short, lukewarm report did not bode well. ${ }^{43}$

Caetani seemed to have anticipated the film's reception: positive for the exposure of its key celebrity - the Duce-but negative for the film's obvious propaganda import. ${ }^{44}$ On February 4 , he wrote again to Mussolini repeating what he had 
written a few days earlier: distributors had asked that all the scenes in The Eternal City that had an obvious propaganda aspect be removed. He sought to reassure the Duce that the film maintained its ideological integrity and that it was doing well in the United States. But the message was clear to those who wanted to hear it: overt propaganda was not the proper way to broadcast the value of the regime in America. ${ }^{45}$

Meanwhile, the trade and general press published their reviews. Known for its coziness with the Mussolini regime, the Saturday Evening Post published a brief, celebratory review of the film, enriched by a few illustrations. "Sir Hall Caine modernized 'The Eternal City' for the screen," it reported, before adding that the film's "unforgettable characters are people of today. Fascists triumph where Caesars fell." ${ }^{46}$ Other reviews, some laudatory and some critical, did not consider the recent historical context of Fascism's rise but, like the SEP, viewed Mussolini cinematically, so to speak, as a seasoned performer and a celebrity film actor. Photoplay began by describing The Eternal City as "one of the most beautiful pictures ever filmed" for its "views of Rome, taken from one of the hills; the shots in the Coliseum; the views along the beautiful roads shaded by Lombardy poplars." 47

Some reviewers who were dismissive of the film's value singled out the Duce's presence. In the February 1924 issue of Life magazine, Robert E. Sherwood described the film as "nonsense on a heroic scale," lacking "a credible story." Still, although carried by "tidal waves of sonorous propaganda," the film showed the "Fascist Napoleon" exhibiting a "deportment on the screen [that] lends weight to the theory that this is just where he belongs." ${ }^{48}$ While a few newspapers had branded Mussolini as an actor as early as November 1922, by 1924 this was an established trope, one that even Valentino's first unofficial publicity agent, Herbert Howe, could not resist. In one of his columns for Photoplay, he congratulated Fitzmaurice, "who made 'The Eternal City' with Barbara La Marr and Benito Mussolini. With Babbie and Benito in the cast the picture certainly should not be lacking in action." ${ }^{49}$ Similarly, Agnes Smith of Picture-Play Magazine found that the film looked "like a news reel plus a fashion show," but even in her sarcastic tone she acknowledged that while "Barbara La Marr acts as the fashion model," Mussolini, as "Italy's pet fire eater, is the star of the newsreel sections." 50

The reviews that emphasized the film's celebrity value appeared side by side with those that trashed its nationwide commercial potential due to its overt propagandistic content. "Pouf, pouf and a barrel of wind. Samuel Goldwyn (not now connected with Goldwyn Pictures) has a flop in 'The Eternal City," wrote an anonymous Billboard reviewer. "High-salaried actors, fares to Italy and expenses while there, $\$ 100,000$ worth of publicity [. . . ] subordinated into an outright plug for Mussolini." The result was that "because of its Roman flavor and the frequent references to Italy's new hero, 'The Eternal City' will find much favor with Italians. It is extremely doubtful if the general public will enjoy it, however." ${ }^{11}$ Similarly, "Rush" (Alfredo R. Greason), the Variety reviewer, complained that the Goldwyn 
production sought "to tie up present day interest in the political upheaval of Italy [rather] than to develop the human interest of the story itself." As a result, the film was going to be "a special interest only to the Italian colony. Whether the rest of the United States will manifest enthusiasm over the alien political situation is something else again." The presence of Mussolini and the king at the film's end, concluded the review, killed the lovers' narrative climax, giving the "picture historic rather than romantic coloring." ${ }^{2}$ Other reviewers complained that Hollywood had converted the original story, with its religious themes, into something completely different: "propaganda for the black-shirted forces of Mussolini." 53 Some even joked ironically that the new collaborative atmosphere between Hollywood and Rome would soon result in Mussolini playing Ben Hur. ${ }^{54}$

Beyond the reviewers' and exhibitors' lack of enthusiasm, the geopolitically sensitive quarters of the film industry deeply appreciated The Eternal City because it marked the first collaboration between Hollywood and a foreign country. In April 1924, in an article in the New York Times, Will Hays argued that "the first purpose of the producers is to make pictures that entertain, films in which costumes and customs of people are correctly portrayed, whether they deal with American, English or French life." He repeated his usual formula that films had to make a "contribution to international amity," and to support his case, he used the example of The Eternal City. Specifically, he referred to Caetani's role. "The Ambassador took the trouble to go over the scenario," he noted, "and satisfied himself that it would be a picture that would reflect Italy in a true light." Hays said that he hoped this would bode well for future productions. "This is perhaps the first instance of an Ambassador accredited to this country taking an interest in an American production to be produced in his own land." 55

Caetani had different feelings. Following his disappointment over The Eternal City, he wondered whether the Italian embassy could further the Duce's cinematic exposure in a more controlled fashion. Mussolini himself wanted to play a more direct role and manage his image directly from Rome. Yet, once again, other mediators intervened and creatively reworked the Duce's image and message in the United States.

\section{THE MAN OF THE HOUR}

The speech in Italian should last three and a half minutes and the one in English the same so that the result would be of greatest impact.

INSTRUCTIONS FOR MUSSOLINI'S SPEECH FOR THE MAN OF THE HOUR (TRANS.) $)^{56}$

In Genoa, on May 11, 1927, a trusted officer of the Biancamano ocean liner received a box with seven film rolls and was asked to deliver it to Cortland Smith, president of Fox Newsreels, at the company's office on West 54th Street in New York City. The day after, an Italian government official in Rome reassured Mussolini's personal 
secretary Alessandro Chiavolini that the package was on its way to its American destination. Ten days later, on May 21, a telegram sent from New York arrived at the Plaza Hotel in Rome, addressed to Edgar L. Kaw, a Fox-Case film soundman. It was from Smith, complimenting Kaw and his colleagues in Fox's outfit no. 1, Ben Miggins and D. F. Whiting, on a job superbly done. "First test from can number 5 shows magnificent picture and perfect sound reproduction. Nothing better has ever been done in either pictures or sound. Will now develop balance and cable you results. Heartiest congratulations to you Miggins and Whiting = Courtsmith." ${ }^{57}$

In the spring of 1927, speaking of "picture" and "sound" together was not customary. The Fox-Case Corporation had pioneered a process by which sound could be physically recorded onto photographic film by adding a sound score along the strip of film frames. The sound-on-film process was a radical improvement over sound-on-disc technology, which required perfect synchronization between a phonograph and a movie projector during exhibition and inevitably led to embarrassing mistakes. With its Movietone sound system, the newly formed Fox-Case Corporation was declaring all-out war against its main competitor, Warner's Vitaphone system. "The kind of motion picture attraction chosen by the new company to introduce its system," Raymond Fielding has noted, "was the sound newsreel," or, we would specify, the celebrity newsreel..$^{8}$ The first Movietone sound film was presented on January 21, 1927, in New York City, eight months before the premiere of The Jazz Singer. But the first commercially significant Fox Movietone film premiered in New York on May 27, 1927, and it showed the most newsworthy person and event of the day: Charles Lindbergh's May 20 takeoff from Long Island for his historic transatlantic flight. While this sound film had no spoken parts, it was a cinematic event that opened the way for more. That was a period in which, to return to Frederic Lewis Allen, "every record for mass excitement and mass enthusiasm in the age of ballyhoo was smashed. Nothing seemed to matter, either to the newspaper or the people who read them, but Lindbergh and his story." 59

To match the Lindbergh craze, the Fox-Case Corporation had already made plans for similar productions, all to be distributed by Fox. A few weeks before, it had allowed Jack Connolly and several technicians to leave for Europe with a mission: record the faces and voices of the most important celebrities of the day. ${ }^{60}$ One of their first stops was Rome, where they had managed to film something unique that had to be kept secret so as not to ruin any promotional plan. Upon receiving the mysterious can no. 5, Fox's New York headquarters were quite pleased because they now had footage that offered a double novelty: for the first time it combined the image and the voice of Benito Mussolini making a speech in both Italian and English. Confidentiality had to be maintained. Kaw immediately telegrammed his mediator with the Italian government, J. P. Spanier, the Western Union Telegraph Company representative for Southern Europe, who was in Rome. In turn, Spanier 


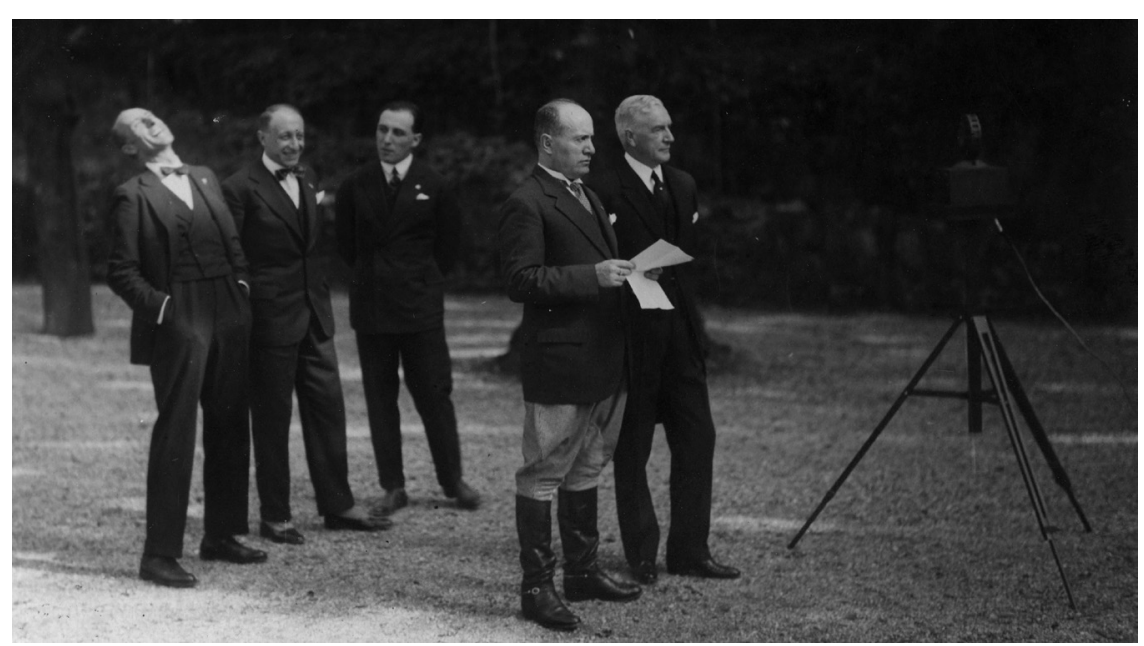

FIgURE 38. On the set of Man of the Hour (Movietone News, 1927), Villa Torlonia, May 6, 1927. From left: Prince Ludovico Spada Veralli Potenziani, governor of Rome; Augusto Turati, general secretary of the Fascist Party; Cornelio Di Marzio, secretary of the Fascists Abroad; Benito Mussolini; and U.S. ambassador to Italy, Henry P. Fletcher.

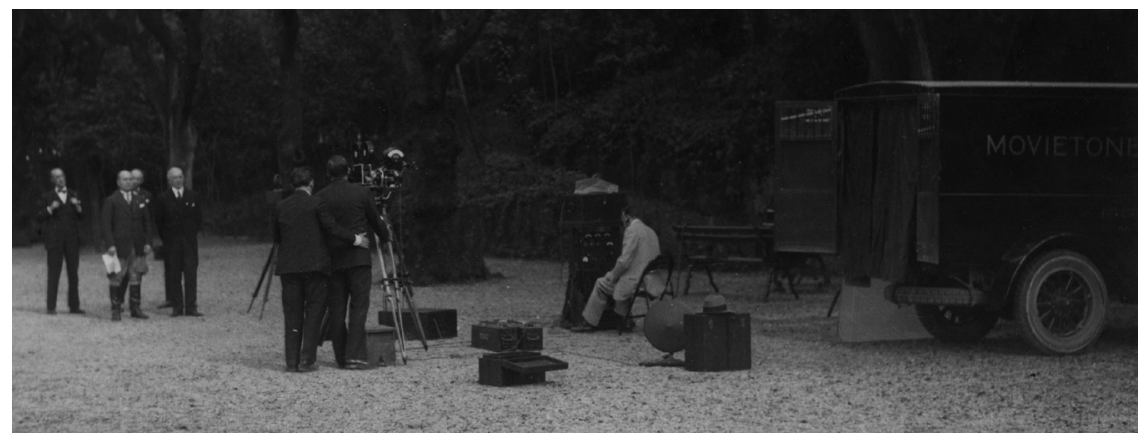

FIGURE 39. The operators of Fox-Case outfit no.1 filming Man of the Hour. Subfolder Fox Film: Pellicola di propaganda italiana, folder P.S.E. Varia 148, box 221, ACS, SPD-CO. Courtesy of Archivio Centrale dello Stato, Rome.

immediately relayed the message directly to the Duce's secretary, Chiavolini. The Duce's immediate circle had high hopes for this recorded speech that was directed at both American and Italian American audiences and could reach millions of people.

A few days earlier, on May 6, two weeks before the first Lindbergh recording, Fox Newsreels producer Jack Connolly, Ben Miggins (cameraman), and Edgar L. Kaw and D. F. Whiting (soundmen) had recorded Mussolini's speech in two languages at Villa Torlonia, the Duce's private residence in Rome (figures 38 and 39). The filming 

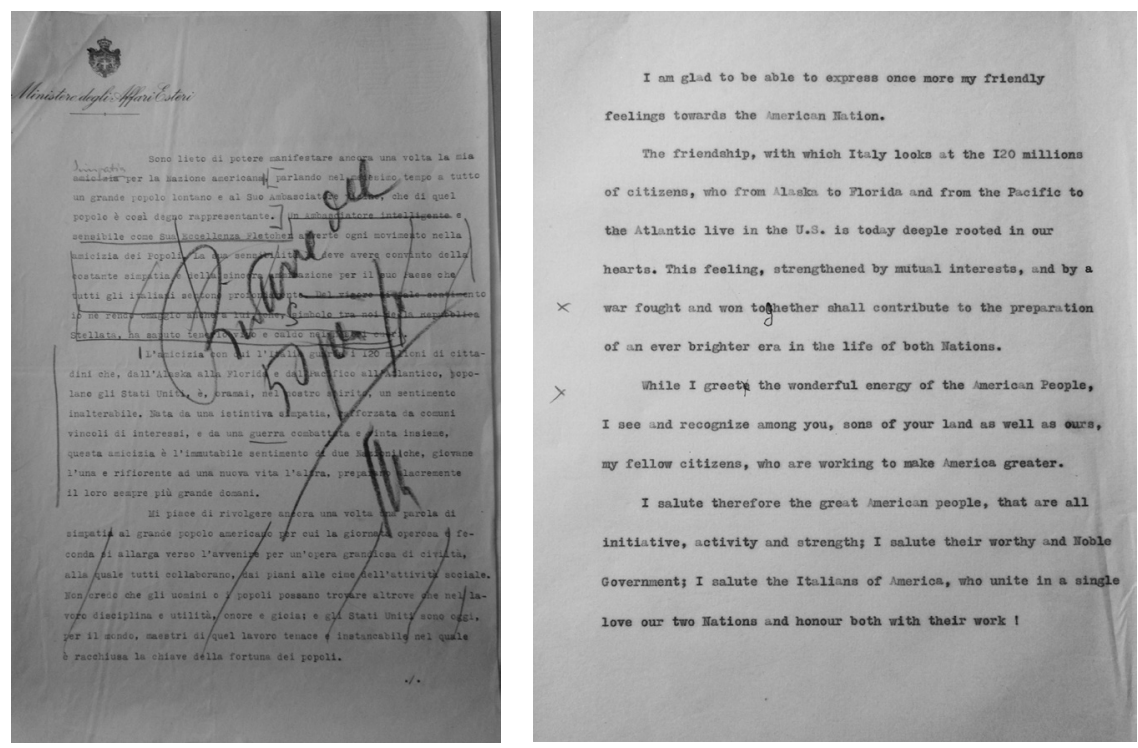

FIGURES 40 and 41. One of the initial drafts of Mussolini's speech, in Italian, to be reduced by $50 \%$, and its final English version. Subfolder Discorso di S.P. per il "Movietone" della Fox Film, 16 August 1927 V, folder P.S.E. Varia 148, box 221, ACS-SPD-CO. Courtesy of Archivio Centrale dello Stato, Rome.

also included the U.S. ambassador to Italy, Henry P. Fletcher, whose role was to introduce the Duce to American audiences. In the footage, Mussolini sports riding breeches, and he was made to walk toward the camera and deliver his talk straight into it. ${ }^{61}$ On the improvised set was also the former ambassador, Richard Washburn Child. Connolly allegedly helped Mussolini with his verbal delivery in English, and he and Child held a large card with the speech written on it for the Duce to read. The press later reported how Mussolini was willing to do multiple takes. During this same assignment, the crew also filmed images of Italian army soldiers on horseback, military bands, parading sailors, and a performance of the Vatican Choir, the latter in place of an interview with the Pope, who had declined their request. ${ }^{62}$

In addition to the challenge of speaking in English, Mussolini had to operate within another constraint - the limited length of his speech. He and his aides went through several drafts in Italian and English to abide by the specific instructions he had been given: "The speech in either in Italian or English could not last more than three and a half minutes." The Italian State Archive in Rome includes both Mussolini's initial, very long, typewritten versions-marked on the first page with what appears to be his penciled note "Ridurre del 50 per \%" [Reduce by $50 \%$ ] -and the final, shortened translation by J. P. Spanier, that best fit the newsreel format (figures $4 \mathrm{O}$ and 41 ). The final version reads: 
I am glad to be able to express once more my friendly feelings toward the American Nation.

The friendship, with which Italy looks at the 120 millions of citizens, who from Alaska to Florida and from the Pacific to the Atlantic live in the U.S. is today deeply rooted in our hearts. This feeling, strengthened by mutual interests, and by a war fought and won together shall contribute to the preparation of an ever brighter era in the life of both Nations.

While I greet the wonderful energy of the American People, I see and recognize among you, some of your land as well as ours, my fellow citizens, who are working to make America greater.

I salute therefore the great American people, that are all initiative, activity and strength; I salute their worthy and Noble Government; I salute the Italians of America, who unite in a single love our two Nations and honour both with their work! ${ }^{63}$

The Fox Movietone newsreel of Mussolini was in and of itself a special event. Even though William Fox paired it with another major attraction, the New York premiere of F. W. Murnau's first American picture, Sunrise, the filming of Mussolini's direct address was not going to be marginalized. Fox promoted it as "the first showing of the Mussolini Movietone, in which the Italian premiere will be seen and heard in a speech, the text of which has been copyrighted by the Fox Film Corporation." ${ }^{4}$ The combination of art and political publicity may strike us for its "incongruousness" and seem "jarring and surprising," to use Bergstrom's words, but it was not a complete novelty for Fox. ${ }^{65}$ According to Fielding, the exceptional footage of Lindbergh's takeoff had been paired four months earlier, on May 27, 1927, with Frank Borzage's masterpiece Seventh Heaven as part of an all-Movietone program. ${ }^{66}$ Since evidence of Fox's in-house documentation about strategies and correspondence is largely absent for this period, one is left speculating about possible explanations. Fox had its own precedents to learn from. In March 1926, Ettore Villani, the Fox Newsreels Rome-based camera operator, had filmed the Fascist Party's seventh anniversary celebration. In the short memo he sent to New York with the footage, he transcribed part of Mussolini's speech and added the note "DUCE: leading captain." Pierluigi Erbaggio has argued that the fact that Villani volunteered this English translation of Mussolini's preferred attribute demonstrates that he knew how much his employer and, by extension, the Fox Newsreels audience obsessed about powerful leaders as worthy film subjects and how little they cared about Fascism as an undemocratic political movement. ${ }^{67}$ It is thus possible to argue that Fox advertised the unusual combination of Murnau with Mussolini (and the other Italian footage) ultimately to promote the novelty of its wide-ranging offerings. Prior to the premiere, in fact, the company advertised the event as having three attractions:

3 Tremendous Features Combined in a Monumental Programme! [.. .] Sunrise, with Symphonic Movietone Accompaniment [. . .] the Vatican Choir, seventy voices of 
sublime power and beauty on the Movietone! [. . .] See and Hear "The Man of the Hour," His Excellency Benito Mussolini, Premier of Italy. He speaks to you and lives before your eyes on the Movietone! Text copyrighted by Fox Film Corp. ${ }^{68}$

A preview was organized by Fox vice president and general manager Winfield Sheenan. Variety's founding editor Sime Silverman covered it on the front page, with a banner headline: "Mussolini's Hope in Screen." In his long review, Silverman did not just celebrate Mussolini's on-screen declaration of amity with the United States as a major political advancement but also praised the Duce for publicly recognizing the impact of the Movietone novelty on news communication. Allegedly, Mussolini had described Movietone as the medium that "can bring the world together, it can settle the differences; it can become the international medium, educator and adjuster; it can prevent war." ${ }^{69}$ From the standpoint of the trade it represented, Variety appreciated that such an international figure had publicly celebrated the new frontier of cinematic news-making as it expanded its reach from mere coverage of exceptional events (i.e., Lindbergh's accomplishment) to more regular reporting on "politics, entertainment, propaganda, or any purpose that may be made appealing." The case of Mussolini was singular, even for Movietone-the "first demonstration of Fox's Movietone with a celebrity" - but it was also emblematic of the general power of the medium to communicate "directness and sincerity." His appearance on screen had the potential of changing people's minds about the dictator (figure 42). "If Movietone carries Mussolini to every incorporated village of this country $[, \ldots]$ millions of Americans will suffer altered opinions on Mussolini," Silverman argued. After all, thanks to the new medium, "a forceful character like Mussolini can go around the universe carrying conviction for whatever he may be discussing." ${ }^{\circ}$

For the New York premiere, Fox chose the Times Square Theatre on 42nd Street and Broadway. The studio also prepared a two-page, double-sided program that described the evening's attractions and sought to drum up excitement over the unprecedented deployment of prerecorded sound scores-a "Symphonic Movietone Accompaniment" for Murnau's film and Mussolini's actual voice for the Movietone News. In the Duce's case, the new technology allowed the premier to address film spectators directly: "He speaks to you, expressing, with his characteristic gestures, his sentiments toward the United States and the Italian-Americans in this country." The result, the program breathlessly claimed, was an unprecedented supply of liveliness and directness: Mussolini "lives before your eyes through Movietone." (figure 43).

The reception was more than positive. The Movietone News featured a notable performance of the Vatican Choir, but the New York Times argued that "the subject that gave one of the most vivid conceptions of the potentialities of the sound and shadow features is that of Benito Mussolini making a speech." ${ }^{71}$ Moving Picture World agreed. According to its reviewer, what mostly impressed the audience of the dual program "was the Movietone accompaniment for the picture and 


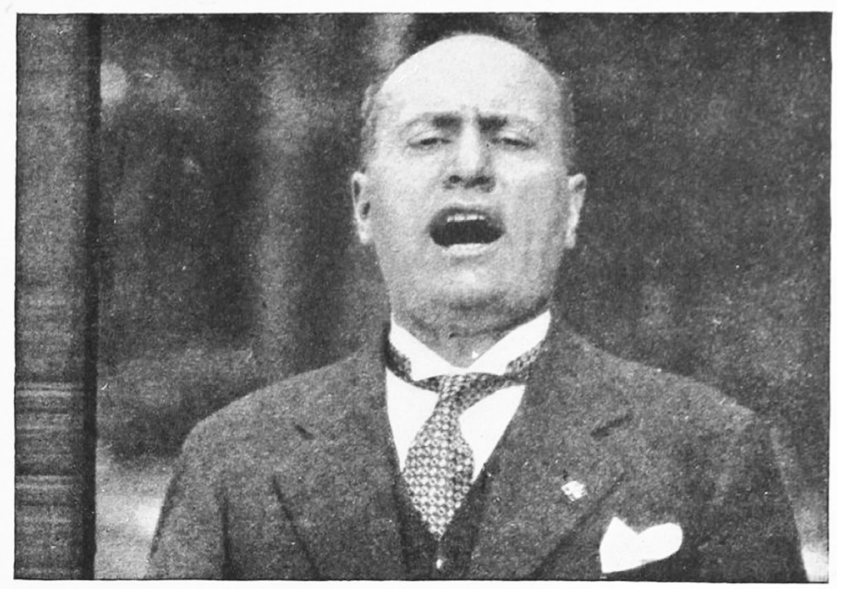

C. Benito Mussolini speaks to you through the marvel of Movietone.

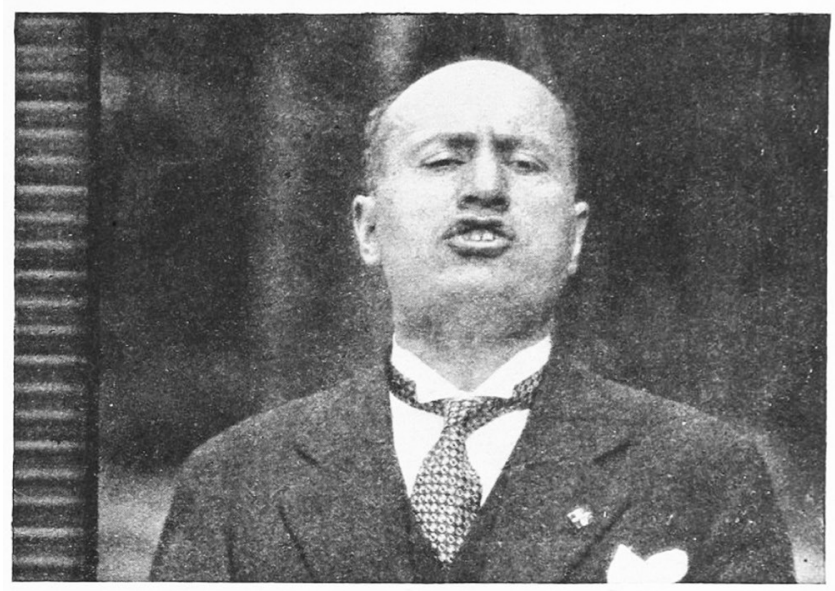

FIGURE 42. Published frames of Mussolini from The Man of the Hour (1927). “The Talking Pictures," Screenland, January 1928, 15.

the Movietone scenes, taken in Italy [through which] the audience saw and heard [...] the great Premier, himself, speaking in English and Italian, exactly as if he was actually in the theater." ${ }^{22}$ The equally enthusiastic Motion Picture News found that "Movietone brings Mussolini face to face with Americans. [. . .] Lifelike it is: amazingly lifelike. A set speech, of course, but the illusion brings the Dictator right into the theatre." ${ }^{33}$ What many found striking, as Screenland put it, was the "enormous close-up of the face of Mussolini. A most remarkable face."74 The same magazine insisted a month later that such a film helps "us know our neighbors 


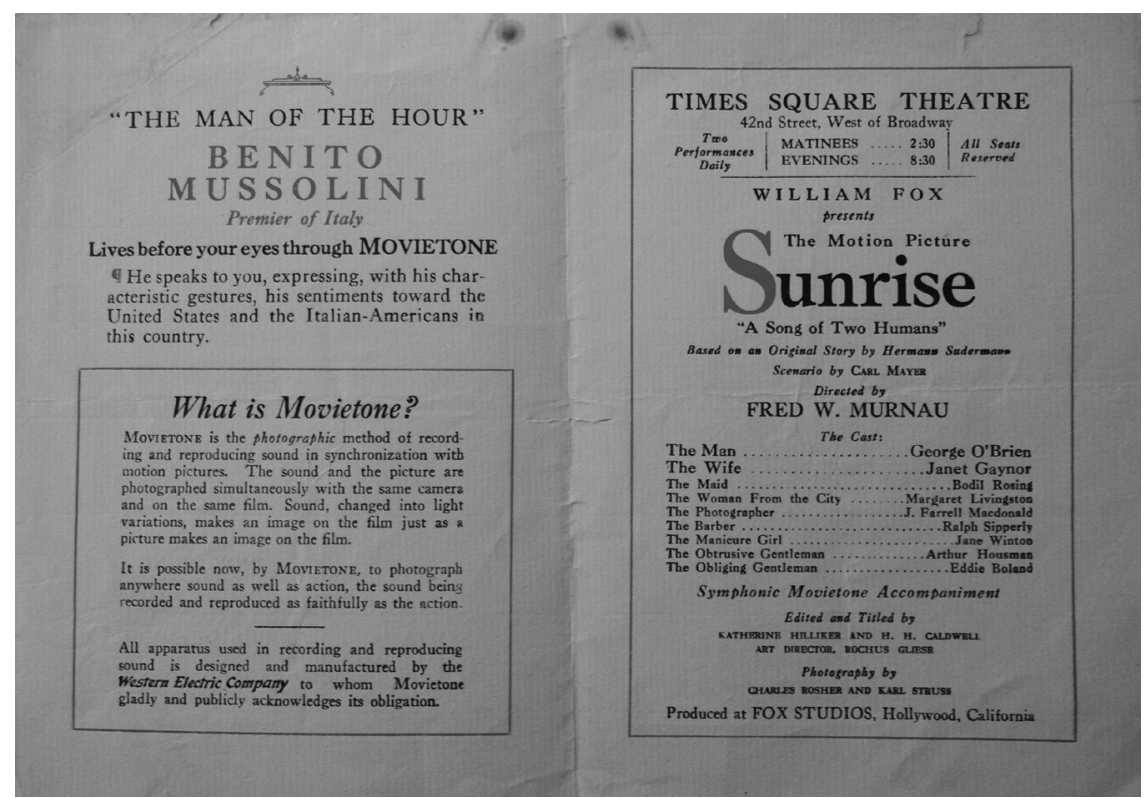

FIGURE 43. Program for double bill of The Man of the Hour, starring Benito Mussolini, and Sunrise, pages 2-3. Folder P.S.E. Varia 148, box 221, ACS-SPD-CO. Courtesy of Archivio Centrale dello Stato, Rome.

on this earth better" and turns distant leaders into "human beings [...] whom we better understand." This article celebrated the new medium with a photographic summary of its recent exploits. It featured frame enlargements from Movietone's footage of President Coolidge welcoming Charles Lindbergh, a close-up of the American aviator, and two medium close-ups of Mussolini, who, the caption read, "speaks to you through the marvel of Movietone."75

The pairing of Murnau with Mussolini lasted three months: by December 12, "the display ads for Sunrise no longer mention any Italian features." ${ }^{6}$ When the program opened in Los Angeles on November 29, The Man of the Hour was not included. Bergstrom explains the absence of the Mussolini footage by pointing out that Los Angeles, unlike New York, did not have a large Italian immigrant population. ${ }^{77}$ Another possible explanation is that the New York experience taught Fox that the combination of the two attractions was not working since they did not attract the same crowd. Fox's Sheenan seemed to have known that it was not possible to advertise both features at once properly. As Bergstrom acknowledges, his "press review a few days before the release of Sunrise directed all the attention to Mussolini and to Movietone." What could be more different than "a charismatic demagogue, speaking forcefully to the audience amid more than 20 minutes of Italian sound and fury" vis-à-vis "a film without dialogue and with an introverted, restrained acting 
style"?78 Further, although popular culture had legitimized Mussolini on a grand scale, a few articles in the business press had been questioning Mussolini's notable experiments in governance on cultural grounds with their praise for the American values of individuality and freedom from state policies..$^{79}$

Making the film happen had not been easy. On the Italian side, the archival record shows evidence of repeated requests to film the Duce by international companies and repeated denials or delayed permissions, a process that may be reminiscent of Wilson's situation before and during World War I. If Mussolini did not trust many of the Hollywood studios' Italian representatives, he had full confidence in his proven mediators, beginning with Child, who had been instrumental in coordinating contacts between the Fox Film Corporation and Mussolini. Not only was Child present during the filming in May at Villa Torlonia, but that summer he also promoted Mussolini's film performance for the readers of the New York Times. ${ }^{80}$

On the American side, the Variety review emphasized that the initiative to film notable Europe personalities with the new technology has been "Connolly's mission." ${ }^{\prime 1}$ As Variety and other papers mentioned, Jack S. Connolly had been the MPPDA's Washington representative, a position that he had held until four months before, when he left to become European director of the Fox Movietone organization. A year after the premiere, he gave an interview to the New York Times on Movietone celebrities. ${ }^{82}$ After the anonymous reporter praised Connolly for having persuaded George Bernard Shaw to be on camera, the conversation inevitably moved to the Duce. "When one first meets Mussolini," Connolly noted, "one is impressed with his vitality, his aggressiveness, his forcefulness and his power." The Fox executive described how Mussolini was willing to rehearse and correct his English pronunciation, demonstrating he was eager to improve himself. Connolly's conclusion about the Italian leader's modern personality shunned any political considerations and remained solidly in the Hollywood domain, primarily due to the Duce's personal style and cinematic appeal:

In my opinion Mussolini is the best dressed man in Italy. His clothes look as if they had been molded on him. No motion picture actor in Hollywood is more careful about his appearance, and I would venture to say that if he ever decided to give up his present position which, incidentally, he likes very much, a dozen picture producers would be after him. ${ }^{83}$

Without referring to the newsreel, but still reverberating in its import, a few months later the New York monthly The Mentor dedicated one of its special issues to Mussolini, the "Man of Italy." Its main article did not hesitate to profile the Duce in the most celebratory manner as the leader of a popular plebiscite:

Superficially Benito Mussolini, the outstanding figure in Europe today, appears to take the ancient Romans for his model. In point of fact, however, the extraordinary career of this modern man of Destiny is far more in the Napoleonic tradition. ${ }^{84}$ 
Similarly, other film periodicals underscored how the Movietone News show of Mussolini impacted both his standing and the future of news making and news reporting. ${ }^{85}$ Screenland contended that "to introduce us to Mussolini, Calvin Coolidge, Bernard Shaw and Charles Lindbergh and at the same time hear their voices, is, so far, the most successful marriage of silence and sound." 86 Picture-Play Magazine noted that "Fox Movietone News quickly became a three-issue-a-week feature" for its ability to reveal "the vocal images" of famous personages, including Mussolini. More than depicting "their likeness," it was a matter of preserving "their living voices, their very personalities, for posterity." ${ }^{87}$ For others, the Movietone News managed to reveal a novel dimension in its coverage of celebrities. "The sound cameras reflect unerringly the dynamic force of Mussolini," declaimed New Movie Magazine, "the quiet force of Henry Ford; the rugged conservatism of the good Calvin [Coolidge]." 88

If the energy of the Duce's performance fueled widespread praise, it also fueled mockery. The British writer George Bernard Shaw had been an early admirer of Mussolini. In 1922 he had welcomed the Duce's rise to power in Italy, observing that amid the "indiscipline and muddle and Parliamentary deadlock," the Italian leader was "the right kind of tyrant." ${ }^{89}$ In contrast, when on June 25, 1928 Fox released George Bernard Shaw Talks to Movietone News, the British writer gently made fun of Mussolini's performative oratory. Shaw posed with his arms around his waist to show what he called the "Mussolini stance," and he included the Fascisti salute. After expressing admiration for Mussolini's hair and brow, he ironically noted that while he could stop assuming the "terrifying Mussolini look" ("I can put it on, take it off, and do all sorts of things"), Mussolini could not. Instead, the Italian leader was "condemned to go through life with that terrible and imposing expression." Interviewed the same year by Motion Picture Classic, Shaw doubled down in irony, adding that "my imitation of Mussolini should have assured you of my ability at character roles." Indicating some of the cracks in the popularity of the Duce, the caption to one of the six film frames illustrating the article reads: "It has been said that there is but one thing funnier than George Bernard Shaw's imitation of Mussolini's expression, and that is Mussolini's expression."9o

These commentaries reveal that if Bernard Shaw could appear as a great character actor, it was because Mussolini had become a character in the Olympus of Hollywood's celebrity-personalities and, as such, he was worthy of praise and ridicule. A December 1928 poster of the Movietone series prominently featured the Duce among the new cinematic format's exemplary subjects, together with Lindbergh and Shaw (figure 44). Similarly, a few months later Fox released a six-reel travelogue, Chasing through Europe (1929), which was devoted not to sites or historical monuments but to the Old World's modern personalities. Mussolini was obviously among them, together with another regular, the Prince of Wales. Reporting on the travelogue, Screenland conceivably reproduced Fox's 


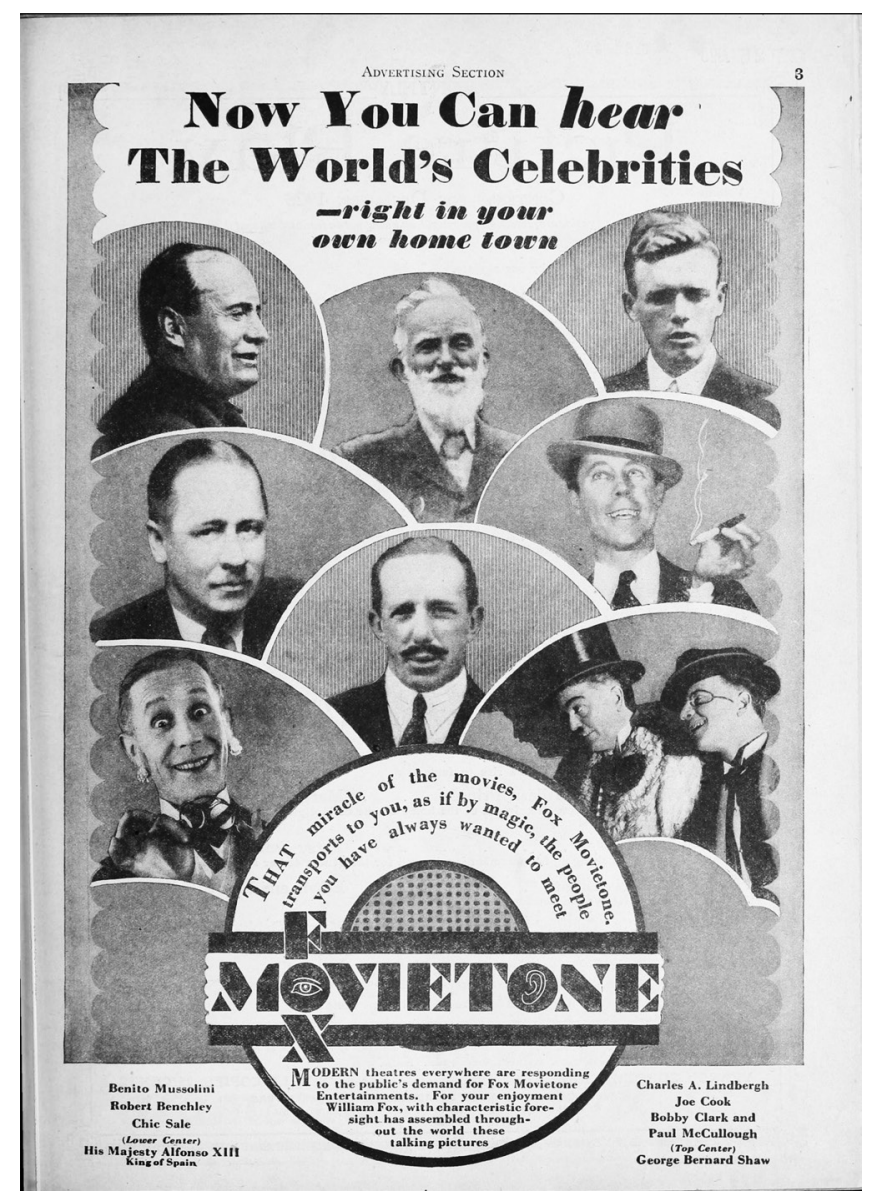

FIGURE 44. Fox Movietone ad featuring celebrities. Picture Play Magazine, December 1928, 3.

promotional slogan: "You will see a dozen celebrities on the screen $[. . .$.$] two kings,$ two dictators, one royal prince, and one Sultan!"91 The same year, in a celebratory volume on the history of motion pictures, Will Hays praised the Fox Movietone initiative for "bringing the world's personalities to the world's people" and thus offering "a very real contribution to the world's welfare." ${ }^{2}$

The bonds among cinema, news-making, and celebrities-no matter their domain of excellence-seemed to have reached a level of natural completion, with Mussolini as a fitting part in it. In truth, behind and before these celebrations were several modest, botched, and rarely successful initiatives by Italian companies, which sought to contribute to the promotion of Fascism and Mussolini's repute in the United States without fully understanding the American cultural marketplace. 


\section{CENSORING AND DISTRIBUTING}

Throughout the 1920s and early 1930s, Italian officials in Washington, DC, were busy mediating between the MPPDA and Italian institutions or even private citizens, who often shared their concerns about negative film representations of Italians in Italian or American productions whether these were exhibited in the United States or elsewhere. This was a concern that had been central to the Italian government even before the days of the March on Rome.

One of the earliest documentable occurrences dates back to August 30, 1922, when Andrea Geisser Celesia di Vegliasco, secretary of the embassy of Italy, complained to Hays about a few films that had depicted Italians "in a very unflattering light" and about Hollywood's "regrettable habit of using the Italian type in filmmaking as an element of villainy, ferocity or grotesque vulgarity." The "belittling of our people," Geisser Celesia added, was "harmful to the bonds of friendship and esteem existing between our two countries." ${ }^{93}$ Hays's response that MPPDA members generally did not intend to negatively portray the "life and character" of nonAmericans and were instead interested in developing "the most cordial international relationship[s]" was prompt but general. ${ }^{94}$ Two months after the March on Rome in late October 1922, an emboldened embassy wrote again to Hays requesting a resolution explicitly tailored to Italy. ${ }^{95}$ The exchanges between the embassy and MPPDA about anti-Italian films continued for years, reaching an apex in the early 1930s, when the Italian diplomatic authorities were alerted about a group of Los Angeles-based Fascists who called themselves "legionaries" and were keen on protesting directly to the studios about the release of films perceived to be demeaning to Italy. ${ }^{96}$ One of these films was The Life of Giuseppe Musolino, the Italian Bandit, which was devoted to the famous Calabrian brigand. ${ }^{97}$ Others included A Farewell to Arms, The Romance of a Dictator, This Is the Night, and The Guilty Generation..$^{8}$ The complaints focused on these films' demeaning association of Italians with crime, laziness, and general ineptitude. ${ }^{99}$ The film that received the most attention, at least according to the volume of the correspondence among diplomatic institutions, private individuals, and Italian American organizations, was Howard Hawks's Scarface (1932). ${ }^{100}$ A case study of Scarface exceeds the framework of this study, but suffice it to say that the embassy's most explicit response consisted of two strategies: put pressure on the MPPDA, even when the producers of said offensive films were not its members, and mobilize Italian American communities at the local level. The second strategy posed the most challenges: the Italian embassy, in fact, was not only engaged in protesting negative representations of Italians in America but also in promoting positive ones.

As it had done before the March on Rome, throughout the 1920 and into the 1930s, the ambassador's office continued to serve as a sort of distribution center for educational productions about Italy to be exhibited in noncommercial outlets (i.e., cultural associations and aid societies). The obvious impetus was to promote 
a positive representation of the country, but another reason for the embassy's involvement was to avoid past mistakes that had occurred when private citizens had been allowed to make direct arrangements with the Italian government to legitimize their dubious commercial plans. ${ }^{101}$ After October 1922, however, the new nationalistic ethos complicated the embassy's mission. Its distribution role faced a constant tension. One the one side were the productions that celebrated the safe image of old, touristic Italy, rich in historical and picturesque attractions but increasingly dated and unappealing. On the other were those that promoted an exciting image of a modern country, whose novel regime and protagonists, however, often attracted harsh criticism and were thus commercially risky. ${ }^{102}$ For instance, after 1922 the Italian officials' attempts to distribute old educational shorts, mostly about Italian customs or the Italians' life during the Great War, were both unsuccessful and the cause of great concern. The new context made these productions appear dangerously propagandistic. ${ }^{103}$

Even after Caetani's tenure ended on February 7, 1925, the embassy's cautious position regarding the value of targeted propaganda, especially about Italian Americans, did not change. The embassy had to counter the misplaced ambitions of Italian-based Fascist officials and journalists who expected that the regime's "visual propaganda," as they labeled it, could overcome language barriers and reach the widest possible audiences. ${ }^{104}$ The embassy felt that it also needed to curb the excesses of Fascist sympathizers in America. Since the Great War, Italy's most prominent citizens in America-the so-called prominenti-had largely become nationalistic, and a few of them had been quite receptive to the ethos of Fascism. The emergence in the United States even before the March on Rome of different nationalist groups, the so-called Fasci di combattimento (Italian Fasci of Combat), the Fascist League of North America, and the Sons of Italy, continued to pose striking challenges to the Fascist government's foreign policy due to the sensitive issue of Italy's war debt. As Caetani once wrote to Mussolini, the Fasci (just like the other groups) "will serve as an example with which to judge Italian Fascism." Caetani had then recommended that in the United States, Fascism "must limit itself to the ideological, philanthropic, and sports arena," arguing that "it cannot assume the character of an activist organization." ${ }^{105}$ Americans were very sensitive to the "threat of political divisiveness among ethnic groups," as Philip V. Cannistraro put it, and Fascist militancy ran the risk of being perceived as meddling with American politics. Any perception of domestic interference by a foreign power would harm the Fascist regime's aspirations for a positive conclusion to the diplomatic negotiations about war debts. ${ }^{106}$ Questions of diplomatic calculations and tact affected Mussolini's response to the new immigrations laws of 1924, which inspired him to consider immigrants as "vectors of Italianità in foreign lands," and to the remarkable press coverage of the Sacco and Vanzetti trial. ${ }^{107}$

The 1926 nationalization of Istituto LUCE complicated the embassy's mission. ${ }^{108}$ In 1925, in fact, LUCE had made private, direct arrangements with the general 
secretary of the Italian Fasci Abroad (Fasci italiani all'estero) for the American distribution of Italian newsreels. ${ }^{109}$ Now the embassy had to intervene to help control and centralize this flow of production by facilitating distribution and exchange agreements between the LUCE and American newsreel companies. These official operations were meant to curb the chaos of roles and distribution deals that the LUCE had contributed to.

By the early 1920s, American newsreel production companies competed for the approximately 16,500 American theatres that exhibited newsreels on a biweekly basis. ${ }^{110}$ To enter this market, LUCE exchanged footage with American newsreel companies, especially with Fox Movietone and Hearst Metrotone, which had offices in Rome. ${ }^{111}$ In turn, these companies broadcast Mussolini's image and biography in the United States, showcased his private and public life, and thus contributed to his standing as political and popular icon. ${ }^{112}$

\section{LUCE IN AMERICA}

Il Duce's facial expressions alone are worth the price of admission. PHOTOPLAY, $1933^{113}$

Between April 1925 and August 1936, Fox's and Hearst's theatrically distributed newsreels featured Mussolini at least once a month as either a primary or secondary attraction. ${ }^{114}$ Throughout that decade, the two companies' collaborations with the LUCE did not overlap exactly, at least according to the official documentation. In Erbaggio's careful research, "Mussolini is present in eighty-four Fox records between April 8, 1925, and October 22, 1935," while Hearst distribution listings refer to "the dictator in ninety-one newsreels issued between September 28, 1929, and August 31, 1936." ${ }_{15}$ The archival record, as Erbaggio warns, is far from accurate: there is footage that is not referenced therein or that falls outside these dates. For instance, Fox's first related newsreel story, Black Shirts, dates back to February 28, 1923. It shows young and adult Fascist followers marching through the streets of Rome and convening at the monument to the Unknown Soldier on the steps of the Altare della Patria. ${ }^{116}$ Similarly, Hearst released an International Newsreel devoted to the Duce before 1929, the brief 1926 Mussolini Smiles!, which presents the Duce as "Italy's strong man," who managed to survive assassination attemptsthree in 1926 alone! —and maintain his good humor. ${ }^{117}$ His titular smile indexed his strength in the face of adversity, and his intact charisma was made even more apparent when juxtaposed against the king's generally austere expression.

These assassination attempts were international knowledge, especially the first one, in which an Irish woman managed to nick the Duce's nose. ${ }^{118}$ Hollywood was obviously intrigued by this incident since it offered one more opportunity to gossip about his popular biography and temperament. When Mussolini met with Fairbanks and Pickford in Rome in May 1926 and asked them to reassure the entire world that he was doing fine, he was referring to this episode. Film 
comedies, too, capitalized on this widespread knowledge to sustain their jokes. For instance, in Leo McCarey's 1926 Mighty like a Moose, starring the popular comedian Charley Chase, a married couple seeks the aid of plastic surgery to correct their unattractive physical traits. The husband (Chase) has protruding front teeth; the wife (Vivien Oakland), a large nose. To be effective, comedic routines and lines rely on social conventions and shared knowledge. After introducing Chase as a man who has been "secretly saving money for months - to take the detour out of his teeth," the film presents Oakland with an amusing parallel intertitle: "If Mussolini had had a nose like hers, his wound would have been fatal."

Even though Erbaggio could not examine the entirety of this newsreel production due to the lack of available footage, he was able to draw a few comprehensive and persuasive conclusions. ${ }^{119}$ American newsreels tended to stress Mussolini's close relationship with symbols of modernity and technological progress and with the novelty of his political communication. Besides his known popular appeal, Fox's decision to make him the first "Movietoned" international political figure in 1927 was due to his image as a leader easily adaptable to the modern sound medium. Unsurprisingly, Fox experimented with this multilingual practice for two other sound newsreels, both released in 1931 and titled Mussolini Promises Peace. They recorded Mussolini speaking in English and French. The dictator affirmed Italy's willingness to pursue peace, "the chief problem which interests the whole humankind," and reinforced this idealistic message by praising the very cinematic technology that was recording him. ${ }^{120}$ Mussolini defined cinema as "the most magnificent discovery of modern times," superior in his view even to the radio, even though, as Fox's synopsis sheet explained, his political statement was also broadcast over radio waves. ${ }^{121}$ Shot while standing behind his desk in his office at Palazzo Venezia in Rome, the dictator was meant to exude, despite his difficulties with the English language, the calm competence of a charismatic modern leader, enamored of the modern film medium. This version of Mussolini looked very different from the man who gave frenzied speeches in front of massive crowds that other films had shown. As such, it was much closer to the image found in another source of visibility that Mussolini embraced mostly in the 1930s, and thus beyond the scope of this study - the eighty-two editorials that Sarfatti ghostwrote for him for Hearst's syndicated newspapers between 1928 and 1935. ${ }^{122}$ Both Mussolini's sound films and editorials were meant to convey an image of a player in world politics and a national leader engaged with modernizing plans. Specifically, his press visibility was peppered with medical terminology, economic references, and concrete, but eloquent examples. Whatever the interests associated with the financial groups who were supporting investments in Italy, Mussolini was a topic of widespread appeal in the popular culture industry. ${ }^{123}$

The swan song of Mussolini's cinematic visibility before his dramatic decline in popularity was Mussolini Speaks (1933), which resulted from years of exchanges between the Istituto LUCE and American newsreel companies and thus 
constitutes a summation of his 1920 s cinematic visibility. Produced by Harry Cohn of Columbia Pictures, the film revealed the longevity of the Duce's appeal and newsworthiness before his popularity declined following his imperialistic campaign in Ethiopia. The title of this seven-reel production resonates both with the previous Mussolini Smiles and with the sensational expectation of hearing Greta Garbo's voice as promised by the promotional slogan "Garbo Talks!" for her first sound film, Anna Christie (1930). Harry's brother Jack had assembled and edited footage of Mussolini and Italian life from different LUCE films. ${ }^{24}$ Harry's idea for the film did not originate from an ideological affinity but from his interest in what one of his biographers calls "the trappings of monarchy." ${ }_{125}$ Cohn's production was designed to be highly enjoyable: it sported a familiarly sensational screen introduction and voiceover by none other than famed radio commentator Lowell Thomas, the creator and promoter of Lawrence of Arabia and for years the voice of countless Fox Movietone newsreels. ${ }^{126}$

The film, which premiered on March 10 at the RKO Palace in New York and on August 11 at the Filmarte Theater in Los Angeles, tells the story of the Fascist leader through his public performances and historical achievements. It opens with the speech, translated in voiceover, that he gave in Naples to celebrate the tenth anniversary of the Fascists' March on Rome in 1922. To illustrate his speech but also to convey the modernity of his arrival on the Italian scene, the film intercuts his words and face with scenes of Italian life such as harvests, sporting events, and engineering projects and with views of typical landscapes, including an erupting volcano (figures 45 and 46). On the military side, there are also scenes of the Duce reviewing troops in North Africa and as he interacts with the Italian people.

The studio's promotional material praised how the film intertwined its dynamic rhythm with the Duce's rapid accomplishments. The film's style dovetailed perfectly with Mussolini's charismatic personality through strategic shot selection, fast editing, and celebratory sound commentary. The studio's own promotional weekly, the Columbia Beacon, opened its February 4, 1933, issue with a long homage to the film, calling it "an exclusive and authentic film autobiography" as if Mussolini had edited the movie himself. ${ }^{127}$ The studio celebrated Mussolini Speaks as "a striking innovation in screen entertainment" with a simple but most eloquent rationale: "Never before has one of the leading figures in world affairs enacted his life's role on celluloid." ${ }^{128}$ While this was an exaggeration, the film helped celebrate cinema itself. "Here, for the first time," the Columbia Beacon insisted, "are the true scope and power of the camera and microphone strikingly revealed." ${ }^{229}$ Thus it was not just that Mussolini was so "cinematic" that a film about his life promised to be a success, but also that cinema, as a private enterprise, had become so relevant in public life that a film about Mussolini could play an important role in civic and political discourse.

The reviews followed the promotional tune. They praised the film as "more than a glorified newsreel" for its synthesis of sound and images. "Clever editing 

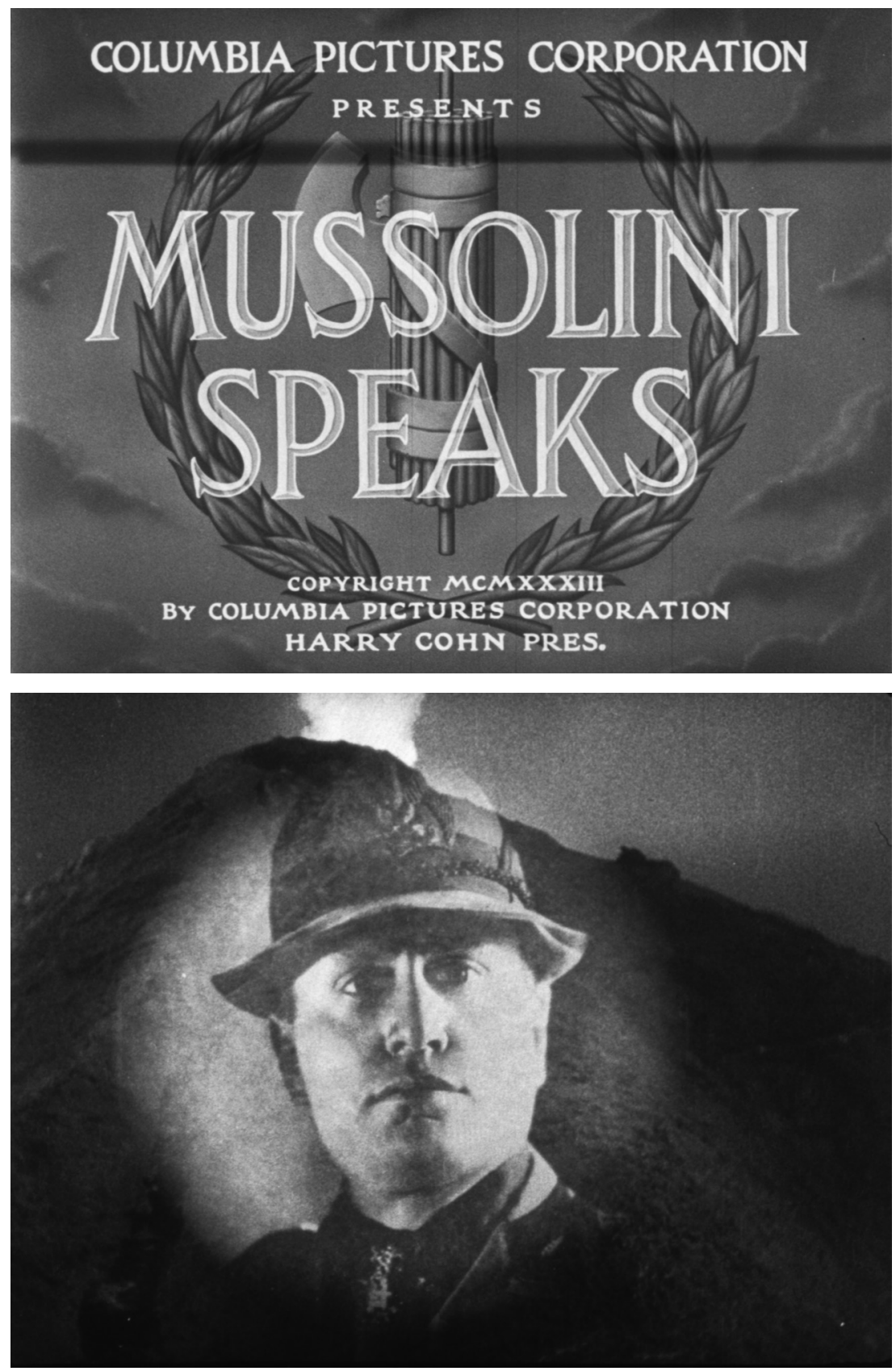

FIGURES 45 and 46. Title screen and close-up of Mussolini in Mussolini Speaks (Columbia Pictures Corp. ( 1933 , renewed 1960 Columbia Pictures Industries, Inc.). All rights reserved. Courtesy of Columbia Pictures. Frame enlargements reproduced from the collections of the Library of Congress, Moving Image Section. 
cuts in on his speech at short intervals," the Film Daily noted, "and shows in actual motion picture views the things that he discusses." ${ }^{130}$ The most eloquent review came out in the Motion Picture Herald, which gave credit to Cohn for producing a "pictorial compilation" about "that genius of personality and leadership who was born Benito Mussolini, son of a laborer, and has become Il Duce, the leader." Interestingly, the review maintained that the political quality of his celebrity status made him worthy of promotional initiatives. Mussolini "is a phenomenon of modern governmental history, and as such is deserving, along those lines, of extensive ballyhoo." ${ }^{131}$

The RKO promotional material insisted on the isomorphism between Mussolini's life and his "moving picture autobiography," even suggesting the dramatic inadequacy of the latter. As a result, "no actor, no matter how gifted, is to be trusted with the gestures, actions, and speech of this international figure." ${ }_{132}$ Similarly, the New York American praised Mussolini's performance for displaying "dramatic quality in speech and action that would be a credit to any motion picture star." 133 There were also negative reviews that focused on the film's quality rather than on the choice of the subject matter. "The picture lacks the cumulative power and sweep of an epic," cried the New York Evening Post. ${ }^{134}$ Similarly, the New York Herald Tribune found the intercut scenes so "unintelligible and worthless" that the result was "entertainment and instruction not even bordering on the mediocre." 135

Within a year, the tide was turning. The Duce's political novelty was expiring and so was the appealing originality of his personality. G. E. W. Johnson in the North American Review commented on the surprising accord between France and Italy by criticizing Mussolini as a bundle of contradictions. He thought that Mussolini was simultaneously a blustering warmonger and a skilled diplomat, "a bombastic pseudo-Caesar who is forever reenacting the crossing of the Rubicon, without having quite made up his mind what do after getting to the other side" ${ }^{136}$ By the time American newspaper correspondent and journalism professor Edwin Ware Hullinger directed another biopic, The Private Life of Mussolini (1938), the interest in the Duce had faded. ${ }^{137}$ A capable self-promoter, Hullinger wrote a long account for Photoplay in which he described the film as "the first screen biography, I believe, ever made of a living world statesman," but he could not but recycle the old slogans of Mussolini as a "star" and "marquee attraction" since these, by the late 1930s, had all but lost their weight. ${ }^{138}$ The last Time magazine cover to feature Mussolini titled the drawing of his older, once gloriously young face, with a funeral-like epigraph, "Aging Dictator."139

Still, throughout the 1920s, many influential reporters, film critics, and even intellectuals condoned Fascism's un-American governance perversions, including the limitation of individual liberties, the one-party state's bureaucratic takeover, and the novel syndicalist and corporatist practices. Long believed to be popular in Italy, Mussolini's mode of mass-mediated plebiscitary governance had, at least for a while, appeared new, daring, and efficient. Many of those praising his leadership would have concurred with the view of Percy Winner, the former Rome-based 
AP correspondent who in a 1928 Current History article argued that "Fascism succeeds not as a theory, a system, a regime or a government, but as a corporeal projection of a successful personality." ${ }^{140}$ Critics and admirers could only agree, however, that with Mussolini a new season of mass-mediated governance had begun. 